the Vienna Convention on the Law of Treaties. To criticize our article as a primary contributor to the ongoing political, economic, and military confrontation (and some speak of economic warfare) would, we humbly suggest, seem itself to be highly unrealistic.

Jordan J. Paust

Albert P. Blaustein

\title{
To The Editor-IN-Chief
}

I read with interest the review in the October 1974 issue of the Journal ${ }^{1}$ of the recently published volume of documents and scholarly writings regarding the South West Africa/Namibia dispute.

The review states that the publication contains "extracts from the 1946-47 debates in the South African Parliament which seem to demonstrate that Prime Minister Smuts acknowledged, at least at that time, an obligation to submit reports regarding the administration of the mandate to the United Nations"; and goes on to say that "this material might have strengthened considerably Applicants' arguments regarding the right of the United Nations to exercise supervisory authority over South West Africa."

The fact is that the Applicants did bring to the Court's attention ample acknowledgment by South Africa concerning its duties to report to the United Nations and the fact that in 1947 it did report. (Memorial of Ethiopia and Liberia, 1 Southwest Africa cases, ICJ Pleadings 32 at 44-45 and $211(1966)$. ) This was probably not even necessary since the Court's previous Advisory Opinion on Southwest Africa had already included a reference to such an acknowledgment and, as a major part of its Opinion, had characterized it as constituting "recognition by the Union Government of the continuance of its obligations under the mandate and not a mere indication of the future conduct of that Government." (International Status of South-West Africa, Advisory Opinion: [1950] ICJ 128 at 135). (At the time the Applicants brought their action, the Court had already specifically ruled in its Advisory Opinion, it will be recalled, that South Africa, in its role as Mandatory, was subject to supervision to be exercised by the United Nations, to whom it had a duty to report.)

The fact of the matter is, of course, that the Court never decided on the Applicants' submission concerning the duty of South Africa to report. Having previously found jurisdiction, the Court in the "merits," decided, in fact, not to rule on the merits but instead in effect reversed its decision on jurisdiction on the ground that Members of the League had not had, and therefore the Applicants in any case did not have, any legal right or interest in claims concerning South Africa's general exercise of the mandate, including its duty to report. This was done despite the Applicants' citing of previous admissions by South Africa at the United Nations and at the Court during arguments preceding the Advisory Opinion that Members of the League had had precisely such a right or interest (ICJ Pleadings, supra 417 at 440,469, and 470-71).

Ten wheelbarrows full of added scholarly material and hundreds of more hours in the library would not have made any difference. The composition of the Court changed between the time it rendered its decision on jurisdiction and the time it rendered its decision on the "merits." The former minority on jurisdiction became, with the help of the casting vote of the Court's President, the new majority, and the Court reversed itself.

1 Slonim, The South West Africa/Namibia Dispute by John Dugard, 68 AJIL 784 (1974). 
(The writer of this letter was one of Counsel for the Applicants during the jurisdictional phase. Accordingly, I have to say that this letter presents my own viewpoint and not necessarily the viewpoint of anyone else.)

LeONARD S. SANDWEISS

Rejoinder to Mr. Sandweiss

Mr. Sandweiss, it would appear, has not closely examined the material which Dugard uncovered and to which I refer in my review. This is to be regretted since the significance of the new evidentiary material becomes apparent only when it is compared to what was actually laid before the 1950 and 1960 Courts on the point in issue-namely the transference of supervisory authority over mandates from the League to the United Nations.

Contrary to Mr. Sandweiss's assertion, the 1950 Advisory Opinion on the International Status of South West Africa in no way found that South Africa had ever conceded an obligation to submit reports on the mandate to the United Nations in lieu of the League. The 1950 Court only found that South Africa's actions confirmed the continued existence of the mandate as an institution; there was no evidence of South African recognition of a transfer of supervisory authority over the mandate from the League to the United Nations. ${ }^{1}$

Only in 1962, in the jurisdictional phase of the South West Africa cases did the Court go beyond the 1950 pronouncement and declare that South Africa's statement (delivered to the final session of the League Assembly) constituted "recognition ... of the continuance of its obligations under the Mandate." The strength of the evidentiary material relied upon by the majority was vigorously challenged by Judges Spender and Fitzmaurice in their joint dissent. It is in this context that the material uncovered by Dugard is so pertinent since he quotes Prime Minister Smuts in 1946 acknowledging before the South African Parliament that reports on the mandate formerly due to the League are henceforth to be submitted to the United Nations (Dugard 102, 114-16). (Indeed he even acknowledges that "the people of the territory can send petitions to UNO.")

This material would have belied the oft-repeated claim of counsel for South Africa that at no time had any South African government acknowledged the right of the United Nations to supervise the South West Africa mandate. At least on this one occasion the Smuts government did acknowledge such supervisory authority. As I stated in my review, this crucial piece of evidence could have strengthened the Applicants' case (on this one point) considerably. Certainly they should not have failed to bring it to the attention of the Court.

SOLOMON SLONIM

1 See in this regard, Slonim, South West Afruca and the United Nations 115-16, n. 22 and 198, n. 45 (1973). 